\title{
Entelektüel Uyarımın Özyeterlilik Üzerindeki Etkisinde Kişi-İş Uyumunun İçsel Atıf Eksenli Aracılık Rolï
}

\section{The Mediatıng Role of Internal Attribution Driven Person-Job Fit in the Effect of Intellectual Stimulation on Self-efficacy}

\author{
Metin Söylemez, ${ }^{\mathrm{a}^{*}}$ Metehan Tolon ${ }^{\mathrm{b}}$ \\ ${ }^{a}$ Dr. Öğr. Üyesi Muş Alparslan Üniversitesi, İktisadi ve İdari Bilimler Fakültesi,Uluslararası İşletmecilik ve Ticaret Bölümü,Muş/Türkiye. \\ ORCID: 0000-0003-0291-2284 \\ b Doç. Dr. Ankara Hacı Bayram Veli Üniversitesi,İktisadi ve İdari Bilimler Fakültesi,İşletme Bölümü, Ankara/Türkiye. \\ ORCID: 0000-0003-0832-3632
}

\section{MAKALE BİLGİSI}

Makale Geçmişi:

Başvuru tarihi: 25 Şubat 2019

Düzeltme tarihi: 26 Şubat 2019

Kabul tarihi: 26 Subat 2019

\section{Anahtar Kelimeler:}

Entelektüel uyarım

Özyeterlilik

Kişi-iş uyumu

\section{ARTICLE INFO}

\section{Article history:}

Received 25 February 2019

Received in revised form 26 February 2019

Accepted 26 February 2019

\section{Keywords:}

Intellectual Stimulation

Self-efficacy

Person-Job Fit

\section{ÖZ}

Bu çalışmada, dönüşümsel liderlik davranışı olarak entelektüel uyarımın, özyeterliliğe etkisi ve bu etkide kişi-iş uyumunun içsel atıf teorisi bakış açısından aracılık rolünün ortaya konulması amaçlanmıştır. Bu amaç doğrultusunda regresyon testlerine dayanan nicel bir araştırma yapılmıştır. Ankara'da faaliyet gösteren bir hizmet işletmesinin 206 çalışanından elde edilen veriler analizlerde kullanılmıştır. Analizler sonucunda, elde edilen bulgularla, entelektüel uyarımın özyeterliliği etkilediği ve bu etkide, kişi-iş uyumunun aracı rolü oynadığı tespit edilmiştir. $\mathrm{Bu}$ çalışma, dönüşümsel liderlik davranışının özyeterlilik algısı üzerindeki etkisinin, işten kişiye doğru kişi-iş uyumu çerçevesinde bilişsel ve içsel atıf eksenli bir sürecin sonucu olduğunu ortaya koymasıyla örgütsel davranış yazınına önemli katkılar sunmaktadır.

\section{Giriş}

Çalışanların görevlerini hangi amaçla yerine getirdiklerinin farkında olmaları ve tüm yetenek, tutum ve potansiyellerini bu amaca ulaşmak için kullanmalarını sağlayacak bilişsel farkındalığa sahip olmaları örgütsel başarım için çok önemlidir. Bu önem bağlamında, yöneticilerin, çalışanlarının öz benliklerini onlardan beklenilen yükümlülükler çerçevesinde şekillendirmeleri, örgütsel başarıya ulaşmak için kritik bir nokta olarak ortaya çıkmaktadır. Bu noktada, çalışanların duygusal ve bilişsel tutumlarını örgütsel amaçlar

\footnotetext{
* Sorumlu yazar/Corresponding author

e-posta: m.soylemez@alparslan.edu.tr
} 
etrafinda değiştirip, yön verme odaklı dönüşümsel liderlik, önemli bir yönetici davranış şekli olarak ortaya çıkmaktadır.

Dönüşümsel liderlik yaklaşımının en az çalışılmış alt boyutlarından biri olan entelektüel uyarımın(Rafferty ve Griffin, 2004); çalışanların, görevlerini yerine getirmede, ekstra çaba göstermelerinde, istekliliklerine ve kendileri hakkındaki inanç/duyguları şekillendirmelerinde etkileri vardır (Stipek, 1983). Entelektüel uyarım aracılığı ile liderler, devamlı olarak takipçilerinin yenilikçi ve inovatif iş yapış ve düşüncelerini destekleyerek takipçilerin kendi öz benlikleri ile ilgili olan inançlarını şekillendirirler. Dahası, entelektüel uyarım ile liderler, takipçilerine olumlu psikolojik duygulanım aşılayarak, performanslarını ve iyi oluşlarını artırırlar(Pirola-Merlo vd., 2002;Salanova vd., 2012). Dönüşümsel liderler entelektüel uyarım davranış biçimi ile yeni fikirleri ve yaratıcılığı hoş karşılayarak takipçilerinin öneri ve fikirlerine göz önüne alarak onlara özel bir önem atfeder. Bu davranış biçiminde, hatalar veya liderin fikrinden farklı fikirler, alenen ve olumsuz olarak eleştirilmez(Bass ve Riggio, 2006). Bu bağlamda, entelektüel uyarım, çalışanların yaptıkları işle ilgili bilişsel farkındalıklarını harekete geçirerek, beceri ve yeteneklerinin yaptıkları iş için yeterli olduğuna dair öznel özyeterlilik algılarını ve işin kendilerine uygun olduğuna dair inançlarını etkiler mi? Kişi-iş uyumunun entelektüel uyarımın oluşturduğu bu bilişsel farkındalık üzerinde bir rolü var mıdır? Bu sorunsallar çerçevesinde, çalışmanın amacı, dönüşümsel liderlik davranışı olan entelektüel uyarımın, özyeterliliğe etkisinde kişi-iş uyumun aracılık etkisini, bireyin öz benliği çerçevesinde içsel unsurlarının etkilediği bilişsel bir süreç olarak açıklamaya çalışmaktır. Bu çalışma dönüşümsel liderlik davranış biçimi olan entelektüel uyarımın özyeterlilik algısı üzerindeki etkisinin, işten kişiye doğru kişi-iş uyumu çerçevesinde bilişsel ve içsel atıf eksenli bir sürecin sonucu olduğunu ortaya koymasıyla örgütsel davranış yazınına önemli katkılar sunmaktadır.

Çalışma, kavramsal çerçevenin sunulmasının ardından, araştırmanın problematiği çerçevesinde kurgulanan hipotezlerin hizmet sektörü çalışanlarından elde edilen veriler doğrultusunda analizini içeren yöntem kısmından oluşmaktadır.

\subsection{Entelektüel uyarım}

Dönüşümsel liderlik bireylerin değiştirildiği ve dönüştürüldüğü bir süreçtir. Dönüşümsel liderler bu değişim ve dönüşümü gerçekleştirirken, dönüşümsel liderliğin boyutlarını oluşturan: İdealize Edilmiş Etki, İlham Verici Motivasyon, Entelektüel Uyarım ve Bireysel İlgi olmak üzere 4 farklı davranış biçimi gösterirler(Bass ve Riggio, 2006). Bu davranışlar, takipçilerin gelişimsel süreçlerini desteklemek amacıyla dönüşümsel liderlere, takipçilerinin motivasyonlarının arttırılmasında ve duygularına karşılık verilmesinde yardımcı olur(Avolio vd., 1999).

Dönüşümsel liderlik, takipçilerin öz benlik algılamalarını kullanarak takipçileri örgüt amaçlarına ve görevlerine bağlayan, ideolojik vurguyu yansıtan, ortak kimliğe ve diğerlerinden üstün olduklarına atıf yapan, liderin dinamizmini ve cesaretini temsil eden, örgütün hedeflerine ve değerlerine bağlılık sağlayan ve hedeflerin başarılması için güven aşılayan davranış biçimidir(Shamir vd.,1998). Dönüşümsel liderlik takipçilerin liderin karizması çerçevesinde, değiștirildiği ve dönüştürüldüğü bir süreçtir(Bass ve Avolio, 1990).

Meindl (1990) karizmayı, sosyal yayılma süreci olarak tanımlamaktadır. $\mathrm{Bu}$ bakış açısına göre lider-takipçi arasındaki karizmatik unsurlar, takipçilerin arasındaki yatay ilişkilerin sonucu oluşur. Karizma, lider kaynaklı değil, takipçi kaynaklıdır. Diğer taraftan karizmatik liderliği, sosyal yayılma süreci olarak tanımlayan Conger ve Kanungo (1987), takipçilerin liderin karizmatik olması hakkında ki tutumu, liderin sergilediği davranışın karizmatik niteliklerine bağlıdır. Karizmatik liderlerin bu nitelikleri: (1) çevresel baskılara ve takipçilerin ihtiyaçlarına olan duyarlılık; (2) mevcut durumun gerekliliklerini tanımlayabilme yeteneği; (3) idealize edilmiş bir vizyon tanımlayabilme ve izlenim yönetimi yeteneklerini yaygın olarak kullanabilmek; (4) vizyonlarına ulaşabilmek için sıra dışı ve yenilikçi yöntemler denemek ve takipçilerini etkilemek için kişisel gücünü kullanmaktır.

Karizmatik liderlik, çoğu araştırmacıya göre atıfsaldır (attribution theory). Karizmatik liderler sadece karizmatik davranışlar sergilemezler, aynı zamanda takipçileri tarafından karizmatik olarak algılanmaları gerekir. Bass ve Avolio (1990)'e göre dönüşümsel liderler, takipçilerinin gözünde karizmatikleşirler. Burada anlatılmak istenen, karizmanın, bir lider davranış çeşidi olmadığı, takipçilerin liderlerine yaptığı bir atfıdır. Bununla beraber liderin geçmiş başarısı ve göze çarpan performansı, takipçilerin liderle ilgili karizma ve etki atfını etkilemektedir(Shamir, 1992).

Yukarıda belirtildiği gibi dönüşümsel liderlik bireylerin değiştirildiği ve dönüştürüldüğü bir süreçtir. Entelektüel uyarım, takipçilerinin yaratıcılığını ve entelektüel çabalarını teşvik eder. Entelektüel uyarım ile dönüşümsel liderler takipçilerinin varsayım ve inançlarını hesaba katarak, inovatif fikir ve çözümlerin ortaya çıkacağı bir iklim oluşturur. Takipçiler problemlere farklı açılardan bakarak yeni yaklaşımları denemeleri noktasında desteklenirler. Dönüşümsel liderler entelektüel uyarım davranış biçimi ile yeni fikirleri ve yaratıcılığı hoş karşılayarak takipçilerinin öneri ve fikirlerine göz önüne alarak onlara özel bir önem atfeder (Bass ve Riggio, 2006).

\section{2. Özyeterlilik ve Entelektüel Uyarım Özyeterlilik İlişkisi}

Özyeterlilik, bireyin, arzulanan sonuçlara ulaşabilmek için gerekli olan davranışları sergileyebilme ve faaliyetleri organize edip başarılı olarak yapma, yeteneğine olan inancidır(Bandura, 1986: 391). Bu nedenle, özyeterlilik belirli bir durumla ilgili olarak bireyin motivasyonel, bilişsel ve davranışsal yeteneklerini harekete geçirebileceğine olan inancidir(Wood ve Bandura, 1989). Bireyin arzulanan sonuçlara ulaşmada, sadece söz konusu yeteneklere sahip olması, tek başına yeterli değildir, aynı zamanda bu yeteneklere sahip olduğuna olan bilince de ihtiyacı vardır(Bandura, 1997). Diğer bir ifadeyle, arzulanan performans sonuçlarına, bireyin performansını etkileyecek yeteneklerin etkisi, bu yeteneklere olan bireyin inanc1, aracıllk etmektedir. $\mathrm{Bu}$, bir bireyin belirli bir performans1 gösterecek yeteneklere sahipken, bu yeteneklere sahip olmadığı yönde kuşku duyduğunda, gerekli performansı gösteremeyerek başarısız olmasını açıklamaktadır. Yetenekli oldukları gözlemlenen bireyler, kendi yeteneklerinden şüphe etmelerine bağlı olarak, kendilerini 
sınırlandırmaları, performansları üzerinde olumsuz etkiye neden olmaktadır. Aksine bireyin, yeteneklerinin farkında olması performansı üzerinde olumlu etkiye neden olmaktadır.

Özyeterlilik kavramının teorik temelleri Rotter (1954)' in Denetim Odağı ve(Heider, 1944) öznel atıf teorileri kapsamında geliştirilmiştir. Denetim odağı, bireyin kendisini etkileyen olayları kendi yetenek, özellik ve davranışlarının sonucu ya da şans, kader ve başkaları gibi kendisi dışındaki faktörlerin etkisi olarak algılamasıdır. Olayların sonuçları üzerinde belirli ölçüde kendi kontrolü olduğuna inanan bireyler içsel denetimli, olayların sonuçlarını kendi dışındaki unsurlardan kaynaklandığına inanan bireyler ise dişsal denetimli bireyler olarak tanımlanabilir. Araştırmacılar, içsel denetim odağının, bireylerin sahip olmayı arzuladıkları kişisel özelliklerle olan olumlu ilişkisini ortaya koymuşlardır. Diğer taraftan, öznel atıf teorisi ise bir durumun sonucunu, içsel veya dişsal olaylara atfetmedir. İçsel unsurlar, bireyin yetenek ve çabasıyla ilgiliyken, dışsal unsurlar ise şans ve işin zorluğu ile ilgilidir. Akabinde, Bandura (1977)'nın sosyal bilişsel teorisinin varsayımlarından, 'birey kendi hayat deneyimini ve olayları kendisi şekillendirebilir ve etkileyebilir ' bakış açısıyla, bireyin kendisinin, kendisini algılayış biçimi çerçevesinde kavramsallaştırılmıştır.

Bandurra 'ya göre özyeterlilik kişisel bir özellik değildir. Belirli durumlarda belirli yeteneklere olan inanç, görev ve kapsam bağlamında değişen bir faktördür(Bandura, 1977). Özyeterlilik, genel bir davranış biçimi değil, belirli bir faaliyet alanı için özelleşmiş bir davranış biçimidir. Diğer taraftan, bireyin farklı alanlarda, farklılaştmış özyeterlilik inancına sahip olması, bireyin karşılaștığı yeni durumlar için özyeterlilik inancına sahip olmasını, olumlu yönde etkilemektedir. Buradan hareketle: Bireyin görevin zorluk derecesinin üstesinden gelmeye yetecek yeteneğe sahip olduğuna olan inancı, başarılı olma olasılığına olan kanaat ve geçmiş başarıların yansıması, özyeterliliği oluşturan unsurlardır(Bong, 2001; Kulviwat vd., 2014; Talley vd., 2011).

Bireyler, özyeterlilik algıları çerçevesinde kariyer olanaklarından birine doğru yönelirler. Ulaşılabilir kariyer hedeflerini göz önüne alarak, kendi ilgilerini çeken kariyer tercihi doğrultusunda azim ve başarı göstermeye çalışırlar(Lent ve Hackett, 1987). Özyetyerlilik algısı yüksek olan bireyler, çalışma hayatı ile beraber katıldıkları örgütte, durumsal taleplere daha iyi cevap vererek, stresli durumlarla başa çıkma stratejileri uygulayarak, yaptıkları işten daha fazla tatmin olurlar ve işlerinin teknik, kişilerarası ve mesleki yönlerinde uzmanlaşmaya çalışırlar(Hackett, 1995). Örneğin Skaalvik ve Skaalvik (2010)' nin araştırma sonuçlarına göre öğretmenlerin özyeterlilik algıları, iş tatminleriyle ilişkiliyken, tükenmişlikleri ile negatif olarak ilişkidir. Diğer taraftan Kanfer ve Hulin (1985)' nin çalışmasına göre bireylerin iş değiştirme niyetlerini yaş, çalışma performansı faktörlerinden daha fazla özyeterlilik algısının etkilediği belirtilmektedir. Bunun yanında işsiz kalan bireylerin yeniden iş bulabilmeye dair olasılığa olan inançları, özyeterlilik tarafından düzenlenmektedir (Clifford, 1989).

Aynı zamanda özyeterliliğin yönetimsel karar alma üzerinde faydaları vardır.(Wood ve Bandura, 1989). Özyeterlilik algısı yüksek yöneticiler, çevredeki firsatlardan yararlanmak isterken, düşük özyeterlilik algısı olan yöneticiler çevrede var olan risklerden kaçınmaya çalışmaktadırlar(Krueger Jr ve Dickson, 1993). Yönetimsel performanslarıyla olumsuz eleştiriye maruz kalan yöneticilerin özyeterlilik algıları azalarak, yönetsel fonksiyonlarının bundan zarar gördüğü ve kötüye gittiği belirtilmektedir. Bunun yanında bu yöneticiler problemlerle yüzleştiklerinde, yönetsel etkililikleri ile ilgili şüpheye düşerek sağduyu ve muhakeme yetenekleri kaybedecek ve örgütsel amaçlarında küçülmeye gideceklerdir(Bandura ve Jourden, 1991). Buna karşılık yönetimsel performanslarıyla olumlu eleştiri alan yöneticiler, kendilerine ulaşılması zor hedefler belirlenmiş olsa bile, özyeterlilik algıları artarak, örgütsel amaçlara karşı daha hırslı olur ve sonuç olarak yüksek örgütsel verimliliğe ulaşılır(Bandura ve Jourden, 1991).

Karizmatik liderlik davranışı olarak dönüşümsel liderlik, yüksek performans beklentilerinin takipçileri tarafından karşılanabileceğine olan güveni ve bu güvenin sağlamasında geçmiş başarı/başarısızlık tecrübelerini ve sosyal desteği kullanarak kendi kapasitelerine inanmalarını sağlayarak, takipçilerin, özyeterlilik algılarını etkilemektedir(Bandura, 1977; Shamir vd., 1993). Aynı zamanda dönüşümsel liderler takipçilerine ilham veren görevler ve daha fazla firsat vererek, çabaları ve performansları hakkında olumlu geri bildirimde bulunur ve sosyal destek verirler. Bu sosyal destek, takipçilerin kendi kapasitelerinin başarılmak istenen görev için yeterli olduğuna dair kanıyı güçlendirerek, özyeterlilik algılarını artırır(Walumbwa vd., 2008). Dönüşümsel liderler entelektüel uyarım ile takipçilerinin özyeterliliklerini güçlendirerek, başarabileceklerini düşündükleri hedeflerden daha zor hedefleri kendilerine amaç olarak edinmelerini ve bu çerçevede kendilerini geliştirmelerini ilham ederler(Liao ve Chuang, 2007). Buradan hareketle aşağıdaki hipotez geliştirilmiştir

$H_{1}$ :Entelektüel uyarımın özyeterliliğe etkisi vardır.

\subsection{Kişi-iş uyumu ve Entelektüel Uyarım Özyeterlilik İlişkisinde Kişi-Işs Uyumu}

Kişi-iş uyumu, bireyin bilgi, beceri ve yetenekleri ile iş gereksinimleri arasındaki uyuma odaklanmaktadır (Carless 2005). Kişi-iş uyumuna bireyin iş gerekliliklerini karşıladığında veya işin bireyin ihtiyaçlarını karşıladığı zaman ulaşılır (Edwards 1991; Kristof-Brown 2000). İş gereklilikleri ve bireyin ihtiyaçları, liderlik gibi örgütsel mekanizmalardan etkilenmektedir (Kristof 1996). Kişi-iş uyumu, işle ilgili belirgin bir özelliğin işte bulunma derecesi ve bu özelliği bireyin karşılama derecesidir (French vd.,1982). Düşük kişi-iş uyumu, memnuniyetsizlik, sıkıntı, endişe, depresyon, rahatsızlık ve somatik şikâyetler açısından düşük derecede iyi oluş ile ilişkili olması beklenmektedir. Araştırmacılar düşük kişi-iş uyumunun iş tatminsizliğine ve gerginliğe sebep olduğunu ampirik araştırmalarla ortaya koymuştur(Kristof-Brown vd.,2005). Düşük kişi-iş uyumu hedonik iyi oluşu azaltmaktadır. Bunun yanında bireyin kişi-iş uyumu sayesinde edindiği hedonik iyi oluş, edindiği mutçuluktan (Eudaimonizm) daha fazladır. Diğer taraftan, hedonik anlamda, bireyin yaptığı işte arzuladığı çevresel şartların sağlanmasıyla oluşan iş tatmini işten kişiye kişi-iş uyumu sağlar. Ancak, motivasyon gibi nedensel süreçler, duygusal durum gibi daha çok kişinin işini ve değerleriyle ne kadar örtüştüğü algılaması kişiden işe kişiiş uyumunu sağlar" (Maslach ve Leiter, 2008, s: 501). Daha net ifadelerle, işin özellikleri ile kişinin beklentileri 
örtüştüğünde kişinin haz alması sağlanırken işe bağlılığını ve tatmini artırılarak işten kişiye kişi-iș uyumu sağlanır, bunun yanında iş, bireye onun motivasyonunu artıracak gereklilikler ve zorluklar sunduğunda, kişiden işe kişi-iş uyumu sağlanarak içsel motivasyon tabanlı işe bağlılık geliştirilir.

Entelektüel uyarımla dönüşümsel liderler takipçilerinin işin özelliklerinden haz almalarıyla oluşan kişi-iş uyumundan öte işin özelliklerinin kişide yarattığı motivasyonel süreçle işten kişiye doğru kişi-iş uyumu sağlarlar. $\mathrm{Bu}$ bağlamda entelektüel uyarım ile kişi-iş uyumu arasındaki ilişki ile ilgili olarak aşağıda belirtilen hipotez geliştirilmiştir.

$H_{2}$ :Entelektüel uyarımın kişi-iş uyumuna etkisi vardır.

Aynı zamanda araştırmacıların özyeterlilik ile yapılan çalışmalar kapsamında yaptıkları meta analiz sonuçlarına göre özyeterlilik ile performans ve motivasyon arasında direkt bir ilişki olduğu gözlemlenmiştir(Bandura ve Locke, 2003; Oude Groote Beverborg vd., 2015; Stajkovic ve Luthans, 1998). Bandura (1982)' ya göre özyeterliliğin, performans ve motivasyon üzerinde ki olumlu etkisinin üç faktörden etkilendiğini belirtmektedir:(1) bireyin hedeflerini özyeterlilik algısı çerçevesinde belirlemesi,(2) arzulanan hedeflere ulaşılacağı olan inançla ortaya konan çabanın yoğunluğu,(3) azmine olan güveni. Aynı zamanda bu üç faktör, bireylerin yaptıkları iş ile ne ölçüde uyumlu oldukları bakımından etkilenmektedir(Kristof, 2002). Bireyin kabiliyetleri ile işin gereklilikleri arasındaki uyum ve bireyin arzuları ile işin özellikleri arasındaki uyum, bireyin özyeterlilik algısını şekillendirmektedir (Edwards, 1991). İşten kişiye doğru oluşan kişi-iş uyumu bireyin özyeterlilik algısını bireyin içsel atfı çerçevesinde etkiler. İşin kolaylığı gibi işten kişinin haz almasını sağlayan unsurlar dışsal atıfla açıklanırken, kişilik, yetenek veya çaba gibi bir faktörler bireyin yaptığı içsel atıfla şekillenmektedir (Manstead ve Hewstone,1999:69-70). Bu çerçevede geliştirilen hipotez aşağıda belirtildiği gibidir.

$H_{3}$ : Kişi-iş uyumunun özyeterliliğe etkisi vardır.

Shamir vd. (1993) karizmatik liderlik ve öz benlik ilişkisinde, karizmatik liderin, takipçilerin dönüşümsel ve motivasyonel olarak etkilenmesini, bir süreç olarak tanımlamaktadır. Bu süreçte, karizmatik liderler, hedeflere ulaşmayı ve sarf edilen çabayı, öz benlik ile ilişkilendirerek, takipçilerin içselleştirmesini sağlarlar. Ayrıca karizmatik liderler, özyeterlilik, özsaygı gibi psikolojik unsurları, takipçilerine olumlu geri bildirimde bulunarak ve onlara güvenerek, arttırırlar. Böylece karizmatik liderlik öz benlik ilişkisinde, liderin davranışı, liderin davranışının takipçinin öz benliği üzerindeki etkisi, liderin davranışın takipçi üzerindeki etkisi ve karizmatik etkiyi ortaya çıkaran motivasyonel süreç, olmak üzere dört unsur bulunmaktadır.

Entelektüel uyarımın özyeterliliği etkilemesinde kişi iş uyumun aracılık rolü oynaması, Shamir vd. (1993)'nin karizmatik ve dönüşümsel liderlerin, takipçilerin öz benliklerinin örgütün amaçlarına ulaşmadaki rolü temelli, etkisini yansıtmaktadır. Dönüşümsel liderler entelektüel uyarım ile takipçilerinin benlik algısını dönüştürerek, işin gereklilikleri ile daha fazla motive olarak işten kendilerine doğru oluşan uyum ile beraber, takipçilerin örgüt amaçlarına katkıda bulunma istekliliğini arttırır(Shamir vd., 1998). Böylece takipçideki oluşacak yüksek düzeydeki özyeterlilik algısı, takipçiyi yetenekleri hakkında daha fazla özgüvenli hale getirerek motivasyonunu arttıracaktır. Bu bağlamda aşağıda belirtilen hipotez geliştirilmiştir.

$H_{4}$ : Entelektüel uyarımın özyeterlilik üzerindeki etkisinde kişi-iş uyumunun aracılık rolü vardır.

\section{Araştırma Yöntemi Ve Bulgular}

$\mathrm{Bu}$ çalışmada entelektüel uyarımın, özyeterlilik üzerindeki etkisinin ortaya konulması ve bu ilişkide kişi-iş uyumunun aracılık rolünün tespit edilmesi amaçlanmıştır. $\mathrm{Bu}$ amaç doğrultusunda nedensel tarama deseninde nicel bir araştırma gerçekleştirilmiştir.

\subsection{Araştırma Modeli}

Araştırma kapsamında entelektüel uyarımın, özyeterliliğe etkilerinin ve bu etkide kişi-iş uyumunun aracılık (mediating) rolünün belirlemek için kurgulanan araştırma modeli Şekil 1'de gösterilmektedir.

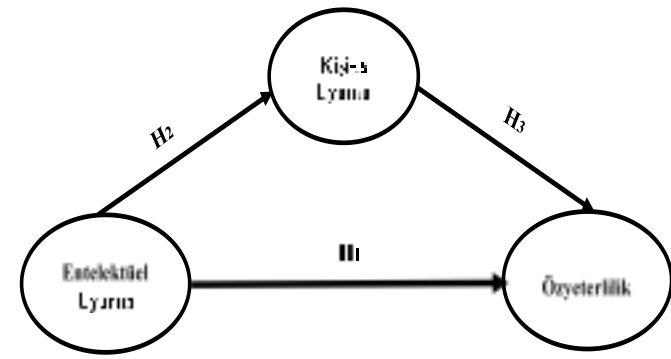

Şekil 1: Araştırma Modeli

\subsection{Anakütle Ve Örneklem}

Araştırmanın anakütlesi, Ankara'da hizmet sektöründe faaliyet gösteren bir işletmenin çalışanlarıdır. Örneklem seçimi ise basit tesadüfi örneklem yöntemi ile yapılmıştır. Bu kapsamda, saha çalışmasının yapıldığı dönemde işletmede çalışan sayısının 510 kişi olduğu anakütlede örneklem büyüklüğü $\% 95$ güven aralığında $\mathrm{e}=\% 5$ hata payı ile $\mathrm{n}=222$ olarak belirlenmiştir. Toplamda 230 kişiye yüz yüze olarak anket uygulanmıştır ve hatalı veya tüm ifadelerin aynı yanıtlandırıldığ 24 anket araştırma kapsamından çıkarılarak 206 anket formu değerlendirme kapsamına alınmıştır.

\subsection{Veri Toplama Süreci Ve Kullanılan Ölçekler}

Veriler, birinci dereceden veri toplamada yaygın olarak kullanılan anket tekniği ile elde edilmiştir. Bununla birlikte anketin yüzeysel geçerliliği sağlamak amacıyla saha çalışmasından önce 30 katılımcıyla pilot uygulama yapılmıştır. Anket formu; demografik bilgiler, entelektüel uyarım, özyeterlilik ve kişi-iş uyumu olmak üzere 4 bölümden oluşmaktadır. Entelektüel uyarım için Bass ve Avolio (1991) tarafından geliştirilen çok faktörlü liderlik ölçeğinin dönüşümsel liderlik ölçeğinin entelektüel uyarım boyutu maddeleri kullanılmıştır. Çalışanların özyeterliliğini ölçmeye yönelik ifadeler Schwarzer ve Jerusalem(1995)'in 10 maddelik özyeterlilik ölçeğidir. Kişi iş uyumu için ise Saks, Ashforth (1997) tarafından geliştirilen 4 maddelik ölçek kullanılmıştır. Anket soruları, 5'li likert tipinde, 'Hiç Katılmiyorum' 'Tamamen Katıliyorum' cevaplama aralığında katılımcılara yöneltilmiştir. 


\subsection{Verilerin Analizi}

Araştırma kapsamında toplanan veriler ile öncelikle katılımcıların demografik özelliklerini incelemek amacıyla frekans analizi yapılmıştır. Sonrasında, araştırmanın normal dağılıma sahip olup olmadığını belirlemek için basıklık ve çarpıklık katsayıları belirlenmiştir. Bir sonraki aşamada, araştırma kapsamında incelenen ölçeklerin yapısal geçerliliğini tespit etmek amacıyla açımlayıcı faktör analizi yapılmıştır. Araştırmaya konu olan değişkenler, arasındaki ilişkileri belirlemeye yönelik korelasyon analizi yapılmıştır. Son aşamada ise araştırma modeli çerçevesinde kurgulanan hipotezler basit regresyon ve aracılık etkisinin analizi, Baron ve Kenny (1986)' nin ortaya koyduğu şartlı aşamalar ve Hayes(2013) 'in geliştirdiği process macro ile test edilmiştir. Aracılık etkisi, Bootstrap örneklemi 5000 olarak belirlenerek, IBM SPSS 24 paket programının yardımıyla test edilmiştir. İstatistiksel analizlerde $\% 95$ güven aralığında çalışılmıştır.

\subsubsection{Katılımcıların Demografik Özellikleri}

Katılımcıların \% 91,3'ü erkek, \% 8,7'si kadındır. Yaş dağılımı incelendiğinde, katılımcıların \% 17 si 18-29 yaş aralığında, \% 43,7 si 30-39 yaş aralığında, \% 21,2 si 40-49 yaş aralığında ve \% 18,1'i 50 ve üzeri yaş aralığındadır. Katılımciların \% 76,2' si evli ve \% 23,8'i bekârdır.

\subsubsection{Araştırma Verilerine İlişkin Tanımlayıcı Istatistikler}

Groeneveld ve Meeden (1984)'e göre araştırmada kullanılan verilerin normal dağılım gösterip göstermediğini belirlemek için çarpıklık ve basıklık katsayılarının -1 ile +1 arasında olması gerekmektedir. Tablo 1 incelendiğinde, araştırma kapsamında ele alınan ölçeklere ilişkin veri setinin çarpıklık ve basıklık değerlerinin istenilen sinırlar arasında olduğunu ve bu nedenle verinin normal dağılım özelliğini gösterdiği belirlenmiştir.

Tablo 1: Tanımlayıcı İstatistikler

\begin{tabular}{lcccc}
\hline \multicolumn{1}{c}{ Ölçekler } & Ortalama & $\begin{array}{c}\text { Std. } \\
\text { Sapma }\end{array}$ & Basıklık & Çarpıklık \\
\hline Entelektüel Uyarım & 3,47 & 0,86 & $-0,42$ & $-0,25$ \\
Özyeterlilik & 3,51 & 0,72 & $-0,24$ & $-0,29$ \\
Kişi-İş Uyumu & 3,21 & 0,80 & $-0,19$ & $-0,03$ \\
\hline
\end{tabular}

\subsubsection{Açımlayıcı Faktör Analizi}

Entelektüel uyarımın özyeterliliğe etkisinde kişi-iş uyumunun aracilık etkisini belirlemek için, öncelikle oluşturulan ölçüm aracının yapı geçerliliğini test etmek amacıyla ölçek maddelerine açımlayıcı faktör analizi uygulanmıştır. Çalışmada madde yükleri için faktör yükü 0,40 olarak belirlenmiştir (Field, 2013). Bu bağlamda, entelektüel uyarım ölçeğinin faktör analizine uygunluğu test edilmiştir. KMO değeri 0.813 ve Bartlett test sonucu ki-kare değeri 355.61 ve $p<0.05$ düzeyinde anlamlı bulunarak, ölçek faktör analizine uygun bulunmuştur. Faktör analizi yapılmıştır. Entelektüel uyarım, tek boyut altında toplanmış ve açıklanan varyansın \% 69,60 olduğu gözlemlenmiştir. Dört boyut altında toplanan dönüşümsel liderlik ölçeğinin Cronbach Alfa değeri hesaplanarak güvenilirlik katsayısının 0,85 olduğu görülerek kabul edilebilir düzey olan 0,70 üzerinde olduğu belirlenmiştir.
Özyeterlilik ölçeğinin faktör analizine uygunluğu test edilmiştir. KMO değeri 0.89 ve Bartlett test sonucu ki-kare değeri 914,07 ve $\mathrm{p}<0.05$ düzeyinde anlamlı bulunmuştur. $\mathrm{Bu}$ sonuçlara göre ölçek, faktör analizine uygun bulunarak, faktör analizi yapılmıştır. özyeterlilik ölçeği tek faktörde toplanmış ve varyans açıklama yüzdesi \%57.59 olarak gözlenmiştir. Tek boyut altında toplanan özyeterlilik ölçeğinin Cronbach Alfa değeri hesaplanarak güvenilirlik katsayısının 0,89 olduğu görülerek kabul edilebilir düzey olan 0,70 üzerinde olduğu belirlenmiştir.

Kişi-iş uyumu ölçeği faktör analizine uygunluğu test edilmiş ve KMO değeri 0.75 ve Bartlett test sonucu ki-kare değeri 256,79 ve $\mathrm{p}<0.05$ düzeyinde anlamlı bulunmuştur. Ölçek, tek faktörde toplanmış ve açıklanan varyansın \% 61,82 olduğu gözlemlenmiştir. Tek faktör altında toplanan kişi-iş uyumu ölçeğinin Cronbach Alfa değeri hesaplanarak güvenilirlik katsayısının 0,79 olduğu görülerek kabul edilebilir düzey olan 0,70 üzerinde olduğu belirlenmiştir. Sonuçlara göre, açıklanan varyans oranları \% 50'nin üzerinde ve Barlett küresellik testleri anlamlıdır. Aynı zamanda güvenilirlik katsayıları 0,70'nin üzerindedir. $\mathrm{Bu}$ sonuçlar ölçeklerin geçerli ve güvenilir olduğunu göstermektedir.

\subsubsection{Korelasyon analizi}

Entelektüel uyarım, kişi-iş uyumu ve özyeterlilik boyutları arasındaki ilişkinin incelenmesi amacıyla boyutların ölçek puanları arasında korelasyon analizi yapılmıştır. Tablo 2' te belirtilen boyutlar arasındaki korelasyon katsayıları incelendiğinde, entelektüel uyarım ve özyeterlilik arasındaki korelasyon katsayısı 0.585 ; entelektüel uyarım ve kişi-iş uyumu arasındaki korelasyon katsayısı 0,259; özyeterlilik ve kişi-iş uyumu arasındaki korelasyon katsayısı 0,365 olarak ilişkilerin anlamlı olduğu görülmektedir.

Tablo 2: Korelasyon Katsayıları

\begin{tabular}{lccc}
\hline & $\begin{array}{c}\text { Entelektüel } \\
\text { uyarım }\end{array}$ & özyeterlilik & $\begin{array}{c}\text { Kişi-iş } \\
\text { uyumu }\end{array}$ \\
\hline Entelektüel uyarım & - & & \\
Özyeterlilik & $0.585^{*}$ & - & \\
Kişi-iş uyumu & $0.259^{*}$ & $0.365^{*}$ & -
\end{tabular}

*p $<0.01 ; \mathrm{n}=206$

Boyutlar arasındaki bu yüksek ilişki değerleri teorik olarak literatürdeki bilgileri destekler niteliktedir. Boyutların arasındaki en güçlü ilişki olan; entelektüel uyarım ile özyeterlilik arasındaki ilişki ve anlamlılığa sahip diğer ilişkiler, modelin tutarlılığını ortaya koyarak literatür bilgilerini desteklemektedir.

\subsubsection{Regresyon Analizleri ve Kişi-iş Uyumunun Aracılık Rolü}

Araştırmada ileri sürülen etki mekanizmalarının varlığı, doğruluğu ve güçleri regresyon analizleri ile incelenmiştir. Ayrıca aracılık etkisinin analizi, Baron ve Kenny (1986)' nin ortaya koyduğu şartlı aşamalar ve Hayes tarafindan geliştirilen SPSS macro model 4 ile test edilmiştir(Hayes, 2013). Aracılık etkisi, Bootstrap örneklemi 5000 olarak belirlenerek, IBM SPSS 24 paket programının yardımıyla test edilmiştir. 


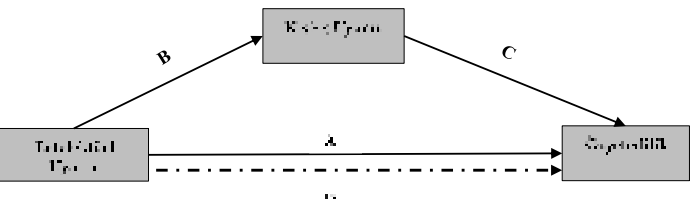

(1)

Şekil 2: Kişi-iş Uyumu Aracılık Modeli

Entelektüel uyarımın özyeterlilik üzerindeki etkisinde, kişiiş uyumunun aracılık rolünü belirlemek amacıyla, şekil 2' de gösterilen model oluşturulmuştur. D harfi ve kesik çizgiler ile simgelendirilen etki, aracı değişken eklenmeden önce entelektüel uyarımın, özyeterliliğe doğrudan etkisini temsil etmektedir. A harfi ile simgelendirilen etki, aracı değişken kişi-iş uyumunun modele dâhil edilmesiyle entelektüel uyarımın, özyeterliliğe doğrudan etkisini temsil etmektedir. B harfi ile simgelendirilen etki, entelektüel uyarımın kişi-iş uyumuna etkisini temsil etmektedir. C harfi ile simgelendirilen etki ise kişi-iş uyumunun özyeterlilik üzerindeki etkisini temsil etmektedir.

Tablo 3: Regresyon Analizi Sonuçları

\begin{tabular}{|c|c|c|c|c|c|c|c|}
\hline \multirow[b]{4}{*}{ Sabit } & \multicolumn{7}{|c|}{ B Etkisi } \\
\hline & \multicolumn{7}{|c|}{ Kişi-iş uyumu } \\
\hline & $\beta$ & SE & $\mathbf{T}$ & $\mathbf{P}$ & $\mathbf{R 2}$ & $\mathbf{F}$ & Sig. \\
\hline & 2,37 & 0,22 & 10,56 & 0,000 & \multirow{2}{*}{0,07} & \multirow{2}{*}{14,68} & \multirow{2}{*}{0,002} \\
\hline \multirow[t]{4}{*}{ Entelektüel } & 0,24 & 0,06 & 3,383 & 0,002 & & & \\
\hline & \multicolumn{7}{|c|}{ C Etkisi } \\
\hline & \multicolumn{7}{|c|}{ Özyeterlilik } \\
\hline & $\beta$ & SE & $\mathbf{T}$ & $\mathbf{P}$ & $\mathbf{R} 2$ & $\mathbf{F}$ & Sig. \\
\hline Sabit & 1,79 & 0,25 & 6,94 & 0,000 & 0121 & 3145 & 0000 \\
\hline \multirow{4}{*}{ Kişi-iş uyu. } & 0,4 & 0,07 & 5,6 & 0,000 & 0,134 & $\mathbf{3 1 , 4 5}$ & 0,000 \\
\hline & \multicolumn{7}{|c|}{ D Etkisi } \\
\hline & \multicolumn{7}{|c|}{ Özyeterlilik } \\
\hline & $\beta$ & SE & $\mathbf{T}$ & $\mathbf{P}$ & $\mathbf{R} 2$ & $\mathbf{F}$ & Sig. \\
\hline Sabit & 1,79 & 0,25 & 6,94 & 0,000 & \multirow{2}{*}{0,13} & \multirow{2}{*}{31,45} & \multirow{2}{*}{$\mathbf{0 , 0 0 0}$} \\
\hline \multirow[t]{4}{*}{ Entelektüel } & 0,40 & 0,07 & 5,6 & 0,000 & & & \\
\hline & \multicolumn{7}{|c|}{ A Etkisi } \\
\hline & \multicolumn{7}{|c|}{ Özyeterlilik } \\
\hline & $\beta$ & SE & $\mathbf{T}$ & $\mathbf{P}$ & $\mathbf{R 2}$ & $\mathbf{F}$ & Sig. \\
\hline Sabit & 1,31 & 0,20 & 6,38 & 0,000 & & & \\
\hline Entelektüiel & 0,44 & 0,04 & 9,27 & 0,000 & 0,39 & 65,33 & 0,000 \\
\hline Kişi-iş uyu. & 0,21 & 0,05 & 4,04 & 0,001 & & & \\
\hline
\end{tabular}

Doğrusal regresyon sonuçları, entelektüel uyarımın özyeterliliği etkilediğini göstermektedir (sig.=0.000). Model, etki ilişkisini pozitif yönde göstermekte $(\beta=0,40)$ ve model açıklayıcılığı anlamlı bir seviyededir $\left(R^{2}=0.13\right)$. Tablo 3 'te belirtilen $\mathrm{D}$ etkisinde görüleceği gibi, bu sonuç $H_{2}$ 'i destekleyerek entelektüel uyarımın özyeterliliği etkilediğini göstermektedir. Diğer taraftan, doğrusal regresyon sonuçları, entelektüel uyarımın, kişi-iş uyumunu etkilediğini göstermektedir (sig. $=0.002)$. Model, etki ilişkisini pozitif yönde göstermekte $(\beta=0,24)$ ve model açıklayıcılığı anlamlı bir seviyededir $\left(R^{2}=0.07\right)$. Tablo 3 'te belirtilen $\mathrm{B}$ etkisinde görüleceği gibi bu sonuç $H_{2}$ 'yi destekleyerek, entelektüel uyarımın, kişi-iş uyumuna etkisini ortaya koymuştur.

Aynı zamanda doğrusal regresyon sonuçları, kişi-iş uyumunun özyeterliliği etkilediğini göstermektedir (sig.=0.000). Model, etki ilişkisini pozitif yönde göstermekte $(\beta=0,40)$ ve model açıklayıcılığ seviyededir $\left(R^{2}=0.13\right) \mathrm{Bu}$ sonuç, Tablo 3 'te belirtilen $\mathrm{C}$ etkisinde görüleceği gibi $H_{3}$ 'ü desteklemektedir.
Tablo 4: Aracılık etkisinde doğrudan ve dolaylı etkiler

\begin{tabular}{ccc}
$\begin{array}{c}\text { Doğrudan Etki } \\
{ }^{1}\end{array}$ & $\begin{array}{c}\text { Doğrudan Etki } \\
\boldsymbol{\beta}\end{array}$ & $\begin{array}{c}\text { Dolaylı Etki } \\
\boldsymbol{\beta}\end{array}$ \\
\hline 0,49 & 0,44 & 0,05 \\
\hline
\end{tabular}

${ }^{1}$ Aracı Değişken Eklenmeden Önce; ${ }^{2}$ Aracı Değişken Eklendikten Sonra

Entelektüel uyarımın özyeterlilik üzerindeki etkisinde kişi-iş uyumunun aracı değişken olarak modele dâhil edilmesiyle, Entelektüel uyarımın özyeterliliğe doğrudan etkisi, A etkisi ile Tablo 3'te belirtildiği gibi anlamlıdır( $\beta=0,44)$. Ve açıklayıcılığı anlamlı bir seviyededir $\left(R^{2}=0.39\right)$. Dolaylı etki, Process Macro Versiyon 3 ile 5000 bootstrap tahmin yaklaşımı ile test edilmiştir(Hayes, 2013). Tablo 4 'te görülen sonuçlara göre dolaylı etki anlamlıdır $(\beta=0,05)$.

Tablo 5:Process Sonuçlar

\begin{tabular}{cccc}
\hline $\begin{array}{c}\text { Dolaylı Etki } \\
\boldsymbol{\beta}\end{array}$ & BootSE & BootLLCI & BootULCI \\
\hline 0,05 & 0,02 & 0,16 & 0,093 \\
\hline
\end{tabular}

Tablo 5'te görüleceği gibi dolaylı etkinin SE değeri 0,02 ve CI değerleri 0,16 ve 0,093 aralığında sıfır noktasını içermeyerek \%95 güven aralığında aracılık etkisinin varlığını göstermektedir. $\mathrm{Bu}$ sonuçlar, $H_{4}$ destekleyerek, Entelektüel uyarımın özyeterlilik üzerindeki etkisinde kişi-iş uyumunun aracılık rolü oynadığını göstermektedir.

\section{Sonuç Ve Değerlendirme}

$\mathrm{Bu}$ çalışmada entelektüel uyarımın özyeterlilik üzerindeki etkisi ve bu iki değişken arasındaki ilişkide kişi-iş uyumunun aracı rolünün ortaya konulması amaçlanmıştır. $\mathrm{Bu}$ amaç doğrultusunda literatür taramasıyla oluşturulan hipotezleri test etmek amacıyla nicel bir araştırma yapılmıştır. Araştırmaya veri toplamak için Ankara'da faaliyet gösteren bir hizmet sektörü işletmesi seçilmiştir. Çalışmada hizmet sektörünün seçilmesinin sebebi, sektörün doğası gereği insan ilişkilerinin davranış ve tutum özelinde ön planda olmasıdır.

Entelektüel uyarımın özyeterliliği etkilemesinde kişi-iş uyumunun aracılık rolü oynaması ile ilgili bulgular, Shamir vd. (1993)'nin karizmatik ve dönüşümsel liderlerin, takipçilerin öz-benliklerinin örgütün amaçlarına ulaşmadaki rolü temelli, etkisini yansıtmaktadır. Dönüşümsel liderler takipçilerin benlik algısını dönüştürerek, takipçilerin örgüt amaçlarına katkıda bulunma istekliliğini arttırır(Shamir vd., 1998). Böylece takipçideki oluşacak yüksek düzeydeki özyeterlilik algısı, takipçiyi yetenekleri hakkında daha fazla özgüvenli hale getirerek motivasyonunu arttıracaktır. Fakat bu çalışmanın sonuçlarından da görüleceği gibi bu motivasyonla ilgili bilişsel süreç, çalışanların yaptıkları işle ilgili uyum durumlarına bağlıdır. Bu çalışmanın odak noktasını oluşturan bu uyum, işin özelliklerinin çalışanlara sağladığı haz verici özelliklerden değil, işten kişiye doğru yapılan işin, çalışanları zorladığı ve meydan okuduğu özelliklerle ilgilidir. Bu bağlamda, işin zorlayıcı ve meydan okuyucu özellikleri liderlerin entelektüel uyarımla çalışanları dönüştürdüğü bilişsel bir süreçtir. Çalışmanın sonuçları, bu süreçte liderler işin zorlayıcı özelliklerini çalışanların tabiatı, niyeti, arzuları ve içsel özellikleri gereği başarabileceği noktasında motive ederek çalışanların öz benliklerini içsel atıfları sayesinde şekillendirerek özyeterlilik algılarını arttırırlar, sonucunu ortaya koymaktadır. 
Çalışmada kısıtlardan kaçılmaya çalışılmışsa da çalışmanın sınırlılığı olduğunu belirtmek gerekmektedir. Çalışmanın teması, öznel ve algıya dair konular olduğundan çalışanların bu konuda dürüst cevaplar vermekten kaçınmış olabilecekleri ve anket çalıșmasının yapıldı ̆ğ dönemdeki ruh hallerine bağlı olarak verdikleri cevapların farklılaşabileceği göz önünde bulundurulmalıdır. Diğer taraftan, gelecek araştırmalarda özyeterlilik ve kişi-iş uyumunun örgütlerde liderlik ile ilişkisi bakımından babacan liderlik, etik liderlik ve otantik liderlik çerçevesinde araştırılması, özyeterliliğin ve kişi-iş uyumunun öncülleri ve ardıllarının anlaşılabilmesi ve yönetilebilmesi açısından gelecek araştırmalara 1 şık tutmaktadır.

\section{Kaynakça}

Avolio, B. J., Bass, B. M., ve Jung, D. I. (1999). Reexamining the components of transformational and transactional leadership using the Multifactor Leadership. Journal of occupational organizational psychology, 72(4), 441-462.

Bandura, A. (1977). Self-efficacy: toward a unifying theory of behavioral change. Psychological review, 84(2), 191.

Bandura, A. (1982). Self-efficacy mechanism in human agency. American psychologist, 37(2), 122.

Bandura, A. (1986). Social foundation of thought and action: A social-cognitive view: Englewood Cliffs.

Bandura, A. (1997). Self-efficacy: The exercise of control. New York, NY, US: W H Freeman/Times Books/ Henry Holt \& Co.

Bandura, A., ve Jourden, F. J. (1991). Self-regulatory mechanisms governing the impact of social comparison on complex decision making. Journal of personality social psychology, 60(6), 941.

Bandura, A., ve Locke, E. A. (2003). Negative self-efficacy and goal effects revisited. Journal of applied psychology, $88(1), 87$.

Baron, R. M., ve Kenny, D. A. (1986). The moderatormediator variable distinction in social psychological research: Conceptual, strategic, and statistical considerations. Journal of personality social psychology, 51(6), 1173.

Bass, B. M., ve Avolio, B. J. (1990). The implications of transactional and transformational leadership for individual, team, and organizational development. Research in organizational change development, 4(1), 231-272.

Bass, B. M., ve Avolio, B. J. (1991). The Multifactor Leadership Questionnaire: Form 5x. Center for Leadership Studies, State University of New York, Binhampton, NY.

Bass, B. M., ve Riggio, R. E. (2006). Transformational leadership. London: Lawrence Erlbaum Associates.

Bong, M. (2001). Between-and within-domain relations of academic motivation among middle and high school students: Self-efficacy, task value, and achievement goals. Journal of educational psychology, 93(1), 23.
Carless, S.A. (2005), 'Person-Job Fit Versus PersonOrganization Fit as Predictors of Organizational Attraction and Job Acceptance Intentions: A Longitudinal Study,' Journal of Occupational and Organizational Psychology, 78, 411-429.

Clifford, S. A. (1989). Cause of termination and self-efficacy expectations as related to reemployment status.

Conger, J. A., ve Kanungo, R. N. (1987). Toward a behavioral theory of charismatic leadership in organizational settings. Academy of management review, 12(4), 637-647.

Edwards, J.R. (1991), 'Person-Job Fit: A Conceptual Integration, Literature Review, and Methodological Critique,' International Review of Industrial and Organizational Psychology, 6, 283-357.

Field, A.(2013).Discovering statistics using IBM SPSS statistics, Sage, Londra

French, J. R. P., Caplan, R. D., \& Van Harrison, R. (1982). The mechanisms of job stress and strain. Ann Arbor, MI: Institute for Social Research.

Groeneveld, R. A. and Meeden, G. (1984), "Measuring Skewness and Kurtosis," Journal of the Royal Statistical Society. Series D (The Statistician), 33, 391-399

Hackett, G. (1995). Self-efficacy in career choice and development. In A. Bandura (Ed.), Self-efficacy in Changing Societies (pp. 232-258): Cambridge University Press.

Hayes, A. F. (2013). Introduction to Mediation, Moderation, and Conditional Process Analysis: A Regression-Based Approach. New York, NY: The Guilford Press

Heider, F. (1944). Social perception and phenomenal causality. Psychological review, 51(6), 358-374.

Kanfer, R., ve Hulin, C. L. (1985). Individual differences in successful job searches following lay-off. Personnel psychology, 38(4), 835-847.

Kristof-Brown, A.L. (2000), 'Perceived Applicant Fit: Distinguishing between Recruiters' Perceptions of Person-Job and Person-Organization Fit,' Personnel Psychology, 53, 643-671

Kristof-Brown, A.L., Zimmerman, R.D., and Johnson, E.C. (2005), 'Consequences of Individuals' Fit at Work: A Meta-Analysis of Person-Job, Person-Organization, Person-Group, and PersonSupervisor Fit,' Personnel Psychology, 58, 281-342.

Kristof, A.L. (1996), 'Person-Organization Fit: An Integrative Review of its Conceptualizations, Measurement, and Implications, 'Personnel Psychology, 49, 1-49.

Kristof-Brown, A. L., K. J. Jansen, and A. E. Colbert. 2002. A policy-capturing study of the simultaneous effects of fit with jobs, groups, and organizations. Journal of Applied Psychology 87:985-93

Krueger Jr, N. F., ve Dickson, P. R. (1993). Perceived selfefficacy and perceptions of opportunity and threat. Psychological reports, 72(3_suppl), 1235-1240. 
Kulviwat, S., C. Bruner II, G., ve P. Neelankavil, J. (2014). Self-efficacy as an antecedent of cognition and affect in technology acceptance. Journal of Consumer Marketing, 31(3), 190-199.

Lent, R. W., ve Hackett, G. (1987). Career self-efficacy: Empirical status and future directions. Journal of vocational Behavior, 30(3), 347-382.

Liao, H., ve Chuang, A. (2007). Transforming service employees and climate: a multilevel, multisource examination of transformational leadership in building long-term service relationships. Journal of applied psychology, 92(4), 1006.

Manstead, Antony ve Hewstone Miles (1999), The Blackwell Encyclopedia of Social Psychology, Blacwell Publishing.

Maslach, C., \& Leiter, M. P. (2008). Early predictors of job burnout and engagement. Journal of Applied Psychology, 93, 498-512.

Meindl, J. R. (1990). On leadership-an alternative to the conventional wisdom. Research in organizational behavior, 12, 159-203.

Oude Groote Beverborg, A., Sleegers, P. J., Endedijk, M. D., ve van Veen, K. (2015). Towards sustaining levels of reflective learning: how do transformational leadership, task interdependence, and self-efficacy shape teacher learning in schools? Societies, 5(1), 187-219.

Pirola-Merlo, A., Hartel, C. E. J., Mann, L., \& Hirst, G. (2002). How leaders influence the impact of affective events on team climate and performance in $R \& D$ teams. The Leadership Quarterly, 13(5), 561-581.

Rafferty, A. E., ve Griffin, M. A. (2004). Dimensions of transformational leadership: Conceptual and empirical extensions. The leadership quarterly, 15(3), 329-354.

Rotter, J. B. (1954). Social learning and clinical psychology.

Saks, A. M., \& Ashforth, B. 1997. A longitudinal investigation of the relationships between job information sources, applicant perceptions of fit, and work outcomes. Personnel Psychology, 50, 395-426.

Salanova, M., Llorens, S., Cifre, E., \& Martínez, I. M. (2012). We need a Hero! Toward a validation of the
Healthy and Resilient Organization (HERO) Model. Group \& Organization Management, 37(6), 785-822.

Schwarzer, R., ve Jerusalem, M. (1995). Optimistic selfbeliefs as a resource factor in coping with stress. In Extreme stress and communities: Impact and intervention (pp. 159-177): Springer.

Shamir, B. (1992). Attribution of Influence and Charisma to the Leader: The Romance of Leadership Revisited 1. Journal of Applied Social Psychology, 22(5), 386-407.

Shamir, B., House, R. J., ve Arthur, M. B. (1993). The motivational effects of charismatic leadership: A selfconcept based theory. Organization science, 4(4), 577594.

Shamir, B., Zakay, E., Breinin, E., ve Popper, M. (1998). Correlates of charismatic leader behavior in military units: Subordinates' attitudes, unit characteristics, and superiors' appraisals of leader performance. Academy of Management Journal, 41(4), 387-409.

Skaalvik, E. M., ve Skaalvik, S. (2010). Teacher self-efficacy and teacher burnout: A study of relations. Teaching teacher education, 26(4), 1059-1069.

Stajkovic, A. D., ve Luthans, F. (1998). Self-efficacy and work-related performance: A meta-analysis. Psychological Bulletin, 124(2), 240.

Stipek, D. J. (1983). A developmental analysis of pride and shame, Human Development, 26, 42-54.

Talley, D., Goodwin, L., Ruzic, R., ve Fisler, S. (2011). Marine ecology as a framework for preparing the next generation of scientific leaders. Marine Ecology, 32(3), 268-277.

Walumbwa, F. O., Avolio, B. J., ve Zhu, W. (2008). How transformational leadership weaves its influence on individual job performance: The role of identification and efficacy beliefs. Personnel psychology, 61(4), 793825 .

Wood, R., ve Bandura, A. (1989). Impact of conceptions of ability on self-regulatory mechanisms and complex decision making. Journal of personality social psychology, 56(3), 407. 